\title{
OCCURRENCE AND PATHOGENICITY OF SERRATIA MARCESCENS AT FISH FARMS IN KAFR EL-SHEIKH GOVERNORATE
}

\author{
M. S. Gado, and Iman A. Abd El-Aziz* \\ Poultry and Fish Dept. *Pathology Dept.
}

\begin{abstract}
An investigation was carried out for unusual disease outbreaks occurred on 5 commercial oreochromis niloticus (O.niloticus) fish farms during the peroid 2003 - 2004, in 3 Districts in Kafr El-Sheikh Governorate. Affected fish exhibited anorexia, sluggishness, variously sized areas of haemorrhage on the skin, corneal opacity and high mortality up to $21.4 \%$. Bacterial isolates from the moribund fish were identified as Serratia marcescens (S.marcescens)by biochemical tests revealed 28 isolates. The virulence properties of this isolates, studied revealed that were highly pathogenic for fish with $L D_{50}$ s ranging from $5 \times 10^{3}$ to $1 \times 10^{5}$. Moreover, the isolates were pathogenic for mice with $L D_{50} 1.6 \times 10^{6}$. Histopathological alterations of the natural and experimental infections are described. The antibiogramme of the isolated S.marcescens was investigated. This study is considered the first record of S.marcescens infection in O.niloticus fish in Egypt .
\end{abstract}

\section{INTRODUCTION}

Bacteria are important pathogens in both wild and cultured fish and are responsible for serious economic losses. Some may cause primarily a surface (skin or gill) infection; most can cause systemic disease. A wide array of bacteria cause infections in freshwater fish. Most pathogens are Gram-negative rods. The only members of the family Enterobacteriaceae which are currently recognized as substantiated fish pathogens are Yersinia ruckeri , Edwardsiella tarda and Edwardsiella ictalurii . However, other 
enterobacteria such as Proteus, Citrobacter,Hafnia, Klebsiella and Serratia species have occasionally been associated with fish disease outbreaks (Bejerano et al., 1979; Llewellyn, 1980; Sato et al., 1982; Gelev et al., 1990; McIntosh and Austin, 1990; Nieto et al., 1990; Gado and $\mathbf{A b d} \mathbf{E l}-\mathbf{A z i z}, 2003 \boldsymbol{a}, \boldsymbol{b})$. Therefore, the possible role of these bacteria in aquac-ulture remains to be determined.

In July 1992, Baya et al. succeeded in isolation of a red pigmented bacterium which resembled a Serratia spp.in pure culture from fish in Back River. Because of the possible public health implications, they performed, an extensive characterization of this microorganism and other Serratia strains, including determination of their virulence properties for fish and homoeothermic animals.

The present study was undertaken to report the isolation and identification Serratia marcescens and all cases of the disease emerging from the investigated fish farms and describe the clinical signs, gross lesion, and histopathology as well as experimental trial for induction of the disease in healthy susceptible fish.In addition, sensitivity test for the isolated bacteria against antimicrobial agents was also achieved.

\section{MATERIALS AND METHODS}

\section{(A) History of the investigated fish farms:}

Five commercial freshwater fish farms, located in 3 Districts in Kafr El-Sheikh Governorate were investigated during the period 2003-2004 for the cause of remarkable red bands distributed all over the body, exophthalmia, corneal opacity, slow wasting, signs of haemorrhagic septicemia, variable mortalities and they acquired a reddish colour along the lateral line and heed.

All fish farms have been treated previously with various antibiotics, antimycotic and vitamins and fed on a commercial ration adlibtum and 
used poultry litters. The source of water in all farms originated from soil agriculture drainage tributaries.

Further details on the history of these farms are given elsewhere.

(B) Postmortem examination and specimens collection:

Sick fish as well as freshly dead fish were removed from affected farm ponds and necropsyed using the methods described by Plumb and Bowser (1983).

Gross lesions were recorded and specimens from kidney,liver,spleen and eye were collected for bacteriological examination.

\section{(C) Bacteriological Examination:}

Specimens from eyes were removed in their entirety as well as from liver,spleen,kidneys and transferred separately to $10 \mathrm{ml}$ volumes of sterile $\left(121^{\circ} \mathrm{c} / 15 \mathrm{~min}.\right) 0.9 \%(\mathrm{w} / \mathrm{v})$ saline in screw capped Universal bottles with vigorous shaking for 5 minutes to dislodge the microorganisms. Thereafter, $0.1 \mathrm{ml}$ volumes were spread over the surface of triplicate plates of tryptic soy agar (TSA;Oxoid) with incubation at $22^{\circ} \mathrm{C}$ for 72 hours. The dominant colony types were purified by successive transfer to fresh media (Baya et al., 1992).

The isolated bacteria were identified by culture morphology, Gramstain and diagnostic tables according to Austin and Austin (1993) and West and Colwell (1984) and Fouz et al. (1990). Biochemical microtest system(API20NE Strip;BioMerieux,Lyon,France)were also used,accding to the manufacturers recommendations (except for an incubation temperature of $25^{\circ} \mathrm{c}$ ), on isolates from TSA .

\section{(D) Histopathological examination :}

Samples from liver, spleen, kidneys and eyes were fixed in $10 \%$ neutral formalin. The washed soft tissues were dehydrated in different concentrations of alcohol, cleared in xylol and embedded in paraffin. $\overline{\text { Kafr El-Sheikh Vet. Med. J. Vol. } 2 \text { No. } 2 \text { (2004) }}$ 
Sections of 5-6 microns were then cut and stained with haematoxylin and eosin (H\&E) stain according to Lillie (1984) .

\section{(E) Pathogenicity test:}

\section{1- For fish :}

The Serratia strains isolated from O.niloticus were tested for patho-genicity in fingerling O.niloticus (4g) and Mugil cephalus(7g) maintained at $20{ }^{\circ} \mathrm{C}$ in freshwater aquaria with aeration. Infectivity trials were condu-cted by intraperitoneal (i.p.) and intramuscular (i.m.) inoculation with bacterial doses ranging from $10^{2}$ to $10^{8}$ (six fish being used per dose) as previously described Toranzo et al.(1983). Mortality was recorded daily over a one-week period and the lethal dose $50 \%$ $\left(\mathrm{LD}_{50}\right)$ was calculated by the Reed and Müench method (1938). Surviving fish were sacrificed after a 3-week period in order to attempt the re-isolation of the inoculated strain and, hence, to assess the possible carrier state and also, subjected to post-mortem and histopathological examination.

\section{2- For homoeothermic animals :}

To assess the degree of virulence for homoeothermic animals we performed a mouse pathogenicity test following basically the procedure of Daily et al. (1981). Briefly, between 5 and 10 BALB/C mice (10- 12weeks-old, 21-25g) were inoculated intraperitoneally with doses ranging from $10^{5}$ to $10^{7} \mathrm{CFU}$ of Serratia strain. Mortalities were recorded after 48 hours inoculation and strains displaying an $\mathrm{LD}_{50} \leq 10^{7} \mathrm{CFU}$ were considered as virulent (Daily et al., 1981 ; Gado and Abd El-Aziz, 2003a).

\section{(F) Antibiogramme:}


The antibiogramme of S.marcescens isolates was investigated against 16 antimicrobial agents using the disc diffusion technique according to Criuckshank et al. (1975). Such procedure was recommended by the National Committee for Clinical Laboratory Standards (1990).

\section{RESULTS}

\section{(A) Epizootiological features of S.marcescens infected farms:}

During the period 2003-2004, 5 commercial O.niloticus fish farms with history of high mortalities were investigated.

The examined fish from all farms suffered from anorexia, sluggishness, slow wasting, exophthalmia, corneal opacity, variously sized areas of hemorrhage on the skin and they. acquired a reddish colour along the lateral line and head (Figs. 1,2) and sudden variably high mortality of $12.5-21.4 \%$, ten days prior to the investigation (Table 1).

\section{(B) Gross lesion:}

Post-mortem examination of freshly dead and killed fish revealed mottled and enlarged liver,gastro-enteritis,spleen enlargement and highly distended gall bladder (Figs. 3,4,5).

\section{(C) Bacteriological examination:}

Preliminary tests allowed us to identify the red pigmented colonies, 1-2 $\mathrm{mm}$ in diameter, isolated from skin, eyes and various internal organs of all investigated fish farms in a virtual pure culture as belonging to the family Enterobacteriaceae and presumptively to the genus serratia. Twenty-eight isolates, which grow on tryptic soy agar revealed motile, Gram-negative, rod shaped organism, could be recovered in a descending frequ-ency order from liver, skin, eyes, intestine, spleen and kidneys (Table 2). 
The Biochemical characteristics of the isolated organisms are shown in table (3).key diagnostic features included the oxidase and catalase negative, indole negative, Voges-Proskauer positive, arginine hydrolase negative but lysine and ornithine positive, and gas production from glucose but not $\mathrm{H}_{2} \mathrm{~S}$.

The inability of S.marcescens to produce acid from arabinose, meliliose, xylose and raffinose allows one to distinguish this species clearly from S.liquefaciens(closely related species,Grimont and Grimont,1984) and S.plymuthica .

\section{(D) Histopathological findings :}

\section{(1) Eyes:}

Cornea: Showed vacuolated cytoplasm with small peripherally located pyknotic nuclei (Fig. 6) .

Iris : Showed containing high amount of melanin pigment which arranged in irregular areas or in linear manner (Fig. 7).

Sclera: Showed necrobiotic changes and degeneration(nuclear lysis)characterized by massive small pyknotic nuclei (Fig. 8).

Choroidal body : Showed vacuolar degeneration, caseous necrosis, dilated blood vessels and massive aggregation of melanin pigment in the form of spherical bodies (Fig. 9).

\section{(2) Liver:}

Hepatocytes showed cloudy swelling, necrobiotic changes, thrombosis and focal aggregation of inflammatory cell. Bacteria, presumed to be S.marcescens, were associated with the foci of necrosis and randomly scattered in colonies without eliciting a cellular reaction (Fig. 10).

\section{(3) Spleen:}


Showed focal coagulative necrosis,clumps of vacuoles, severe depletion of lymphoid follicles, severe congestion of blood vessels and haemorrhages (Fig. 11).

\section{(4) Kidneys:}

Showed haemorrhages, congested blood,cloudy swelling and necrobiotic changes in the renal tubules and coagulative necrosis surrounded by vacuolated tubules.

\section{(E) Experimental results:}

\section{(1) For fish:}

The virulence assays demonstrated that regardless of the inoculation route, the S.marcescens isolate was pathogenic for O.niloticus(mean $\mathrm{LD}_{50}$ of $\left.1 \times 10^{5}\right)$. Furthermore, in the fish injected intramuscularly the time to death was shorter (1-3 days) than in the fish inoculated intraperitoneally (1-7 days). Some of the dead O.niloticus showed strong necrosis of muscular tissues,signs of haemorrhagic septicemia and they acquired a reddish colour along the lateral line and head probably due to the multiplication of the bacterium and the concomitant synthesis of the prodigiosin pigment. Bacterial re-isolation from infected fishes were successful (Table 4).

Histopathological results were nearly similar to those observed in naturally infected fish (Figs. 12-14) .

Fish of the control group remained clinically healthy and showed neither pathological lesions nor S.marcescens isolation .

\section{(2) For mice:}

The virulence assays in mice indicated that S.marcescens strain can be considered as virulent since they displayed an $\mathrm{LD}_{50}$ of about $10^{6}$ live cell (Table 4) .

\section{(F) Antibiogramme:}


Results of sensitivity testing of 28 S.marcescens isolates are showed in (Fig. 15) . All tested isolates (100\%) showed high sensitivity to enrofloxacin and danofloxacin while $90 \%$ of them were sensitive to flumequine and oxolonic acid, $80 \%$ to sulfamethoxole plus trimethoprim,70\% to kitassmycin, $60 \%$ to lincospectin, $50 \%$ to amoxycillin, $40 \%$ to oxytetracyclin, and $30 \%$ to ampicillin.

None of the isolates was susceptible to chloramphenicol, colistin sulfate, streptomycin, gentamycin, erythromycin, and neomycin.

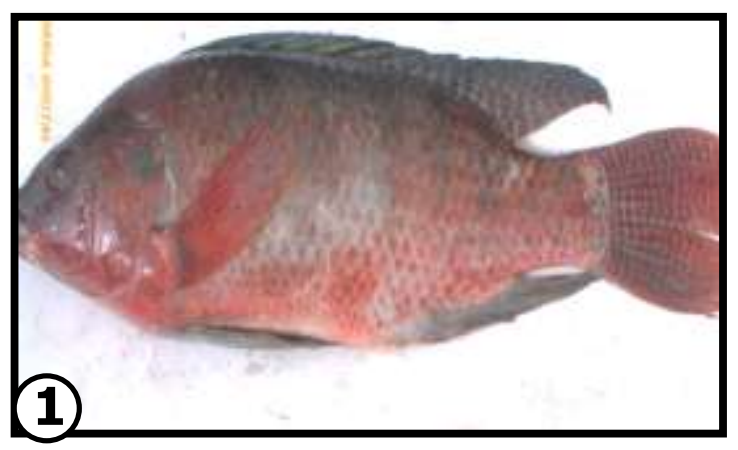

Fig.(1):O.niloticus fish naturally infected with S.marcescens, showing variously sized areas of haemorrhages on the skin.

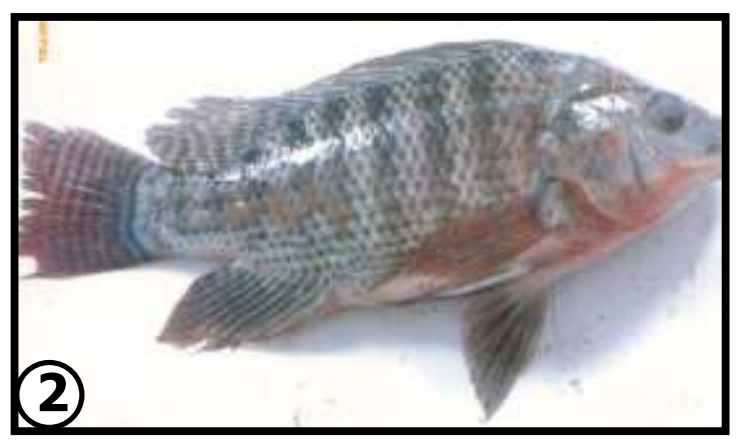

Fig. (2): O.niloticus fish naturally infected with S.marcescens, showing exophthalmia and corneal opacity. 


\section{(3)}

Fig.(3):O.niloticus fish naturally infected with S.marcescens, showing enlarged mottled liver.

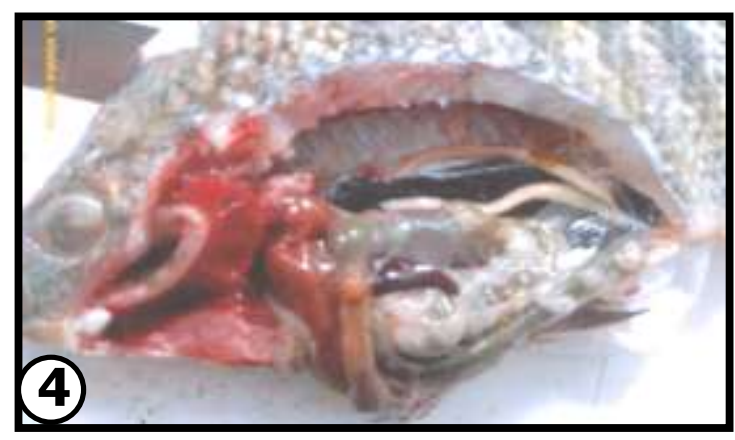

Fig. (4): O.niloticus fish naturally infected with S.marcescens, showing gastroenteritis and spleen enlargement.

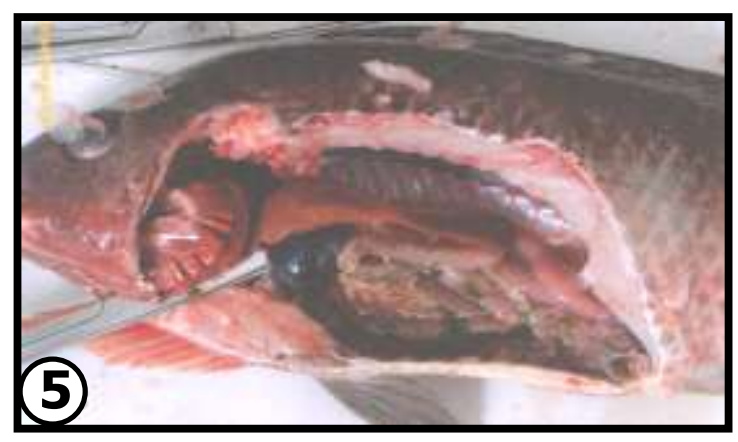

Fig. (5): O.niloticus fish naturally infected with S.marcescens, showing highly distended gallbladder.

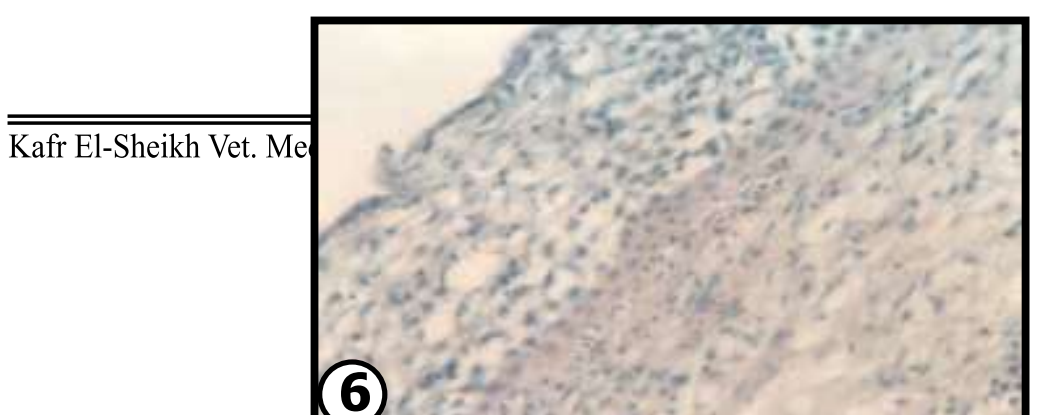


Fig. (6): Sections in eye (Cornea) of O.niloticus naturally infected with S.marcescens, showing a cellular vacuolated cytoplasm with small peripherally located pyknotic nuclei [H\&Ex400].

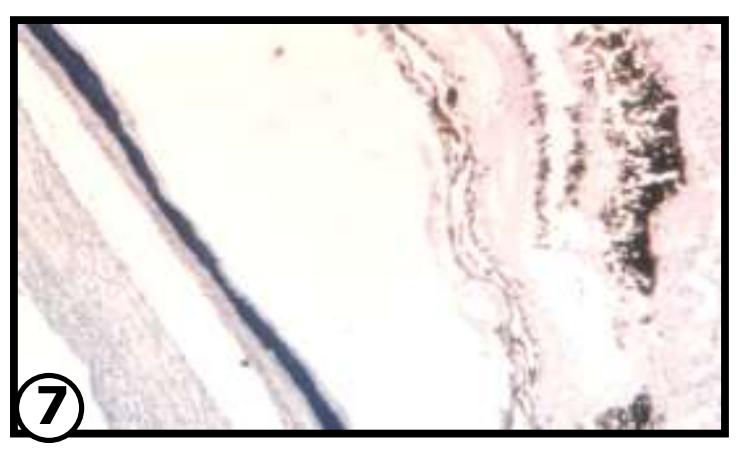

Fig.(7):Sections in eye(Iris)of O.niloticus naturally infected with S.marcescens, containing high amount of melanin pigment[H\&Ex100].

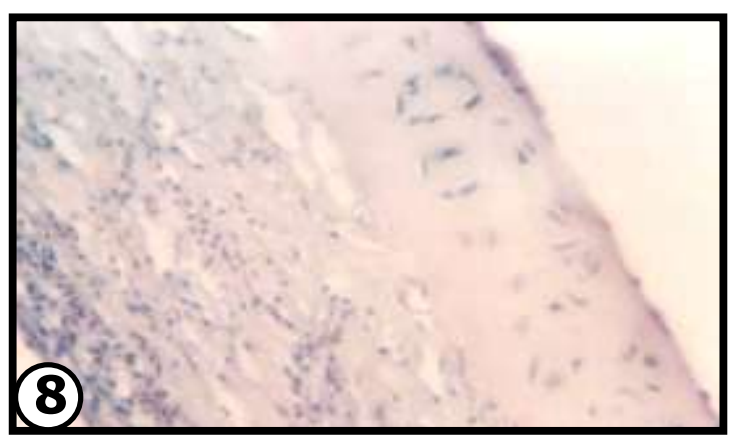

Fig. (8): Sections in eye (Sclera) of O.niloticus naturally infected with S.marcescens, showing a necrobiotic changes and degeneration with massive small pyknotic nuclei [H\&Ex400] . 


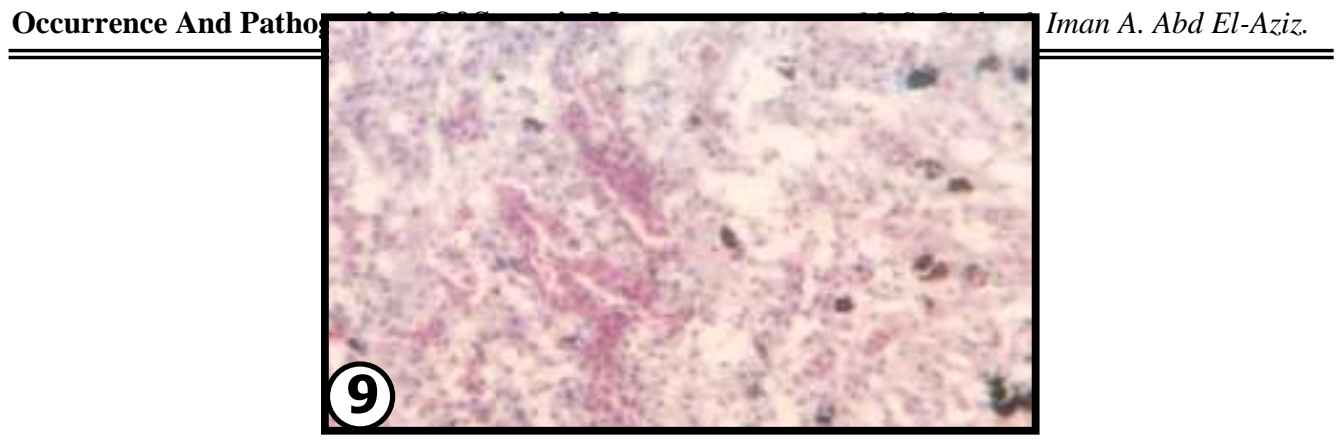

Fig. (9): Sections in eye (Choroidal body) of O.niloticus naturally infected with S.marcescens, showing a vacuolar degeneration, necrosis, dilated blood vessels and massive aggregation of melanin pigment [H\&Ex400].

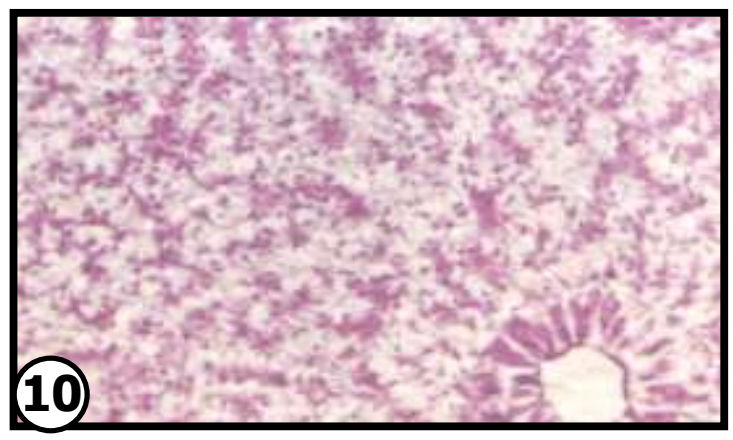

Fig. (10): Sections in liver of O.niloticus naturally infected with S.marcescens, showing cloudy swelling,necrobiotic changes, haemorrhage and focal aggregation of inflammatory cells [H\&Ex400].

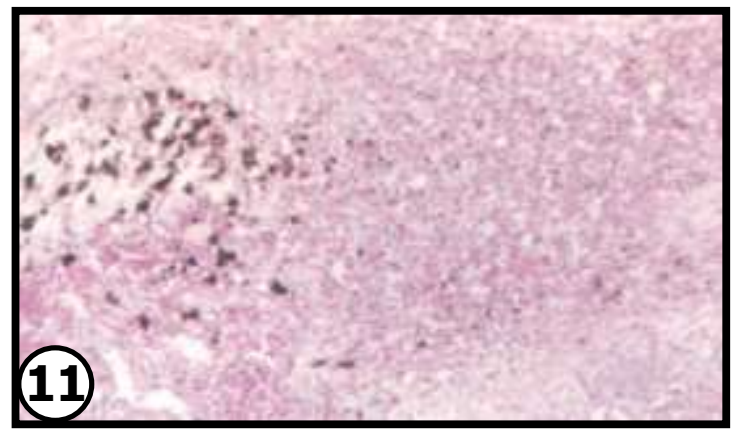

Fig.(11): Sections in spleen of O.niloticus naturally infected with S.marcescens, showing severe depletion of lymphoid follicles, focal coagulative necrosis and haemorrhages [H\&Ex200].

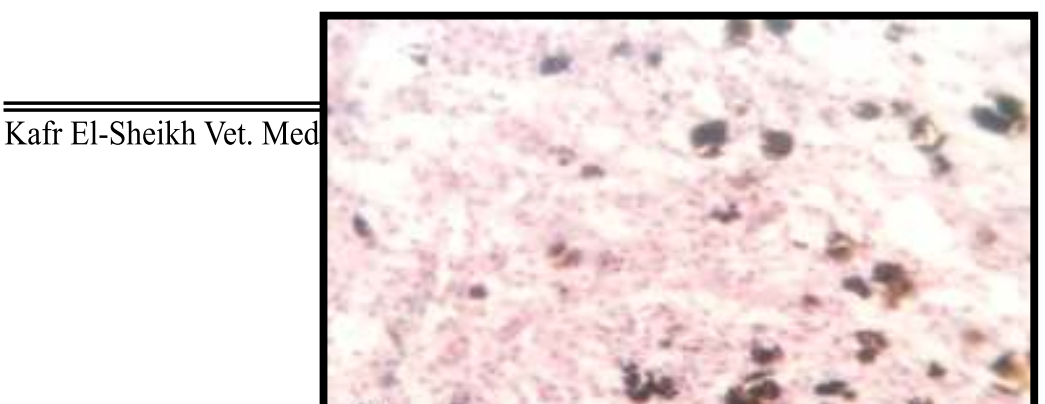




\section{(12)}

Fig. (12): Sections in eye (Choroidal body) of O.niloticus experimentally infected with S.marces-cens, showing a massive aggregation of melanin pigment, haemerrhages, necrosis and vacuolar degeneration [H\&Ex 400] .

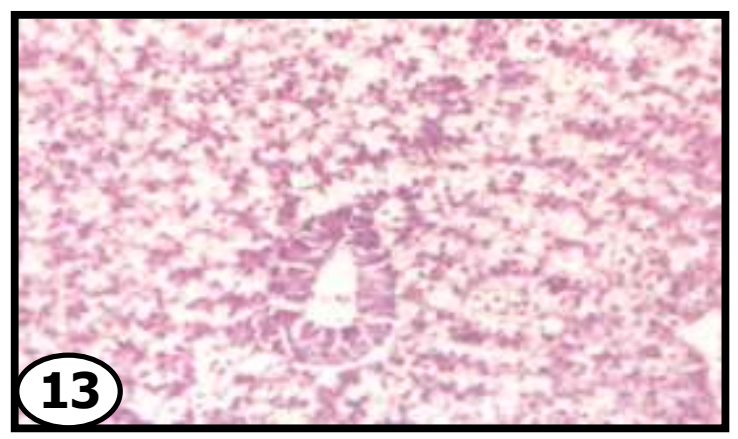

Fig. (13): Sections in liver of O.niloticus experimentally infected with S.marcescens, showing necrobiotic changes, hydropic degeneration, haemerrhages and focal aggregation of inflammatory cells [H\&Ex400] .

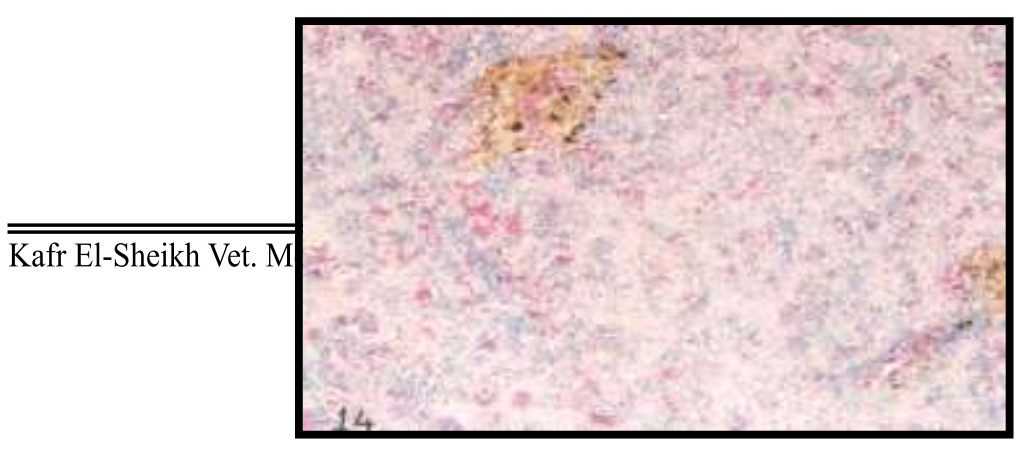




\section{(14)}

Fig. (14): Sections in spleen of O.niloticus experimentally infected with S.marcescens, showing severe depletion of lymphoid follicles, degenerative changes in lymphocytes and haemerrhages [H\&Ex400].

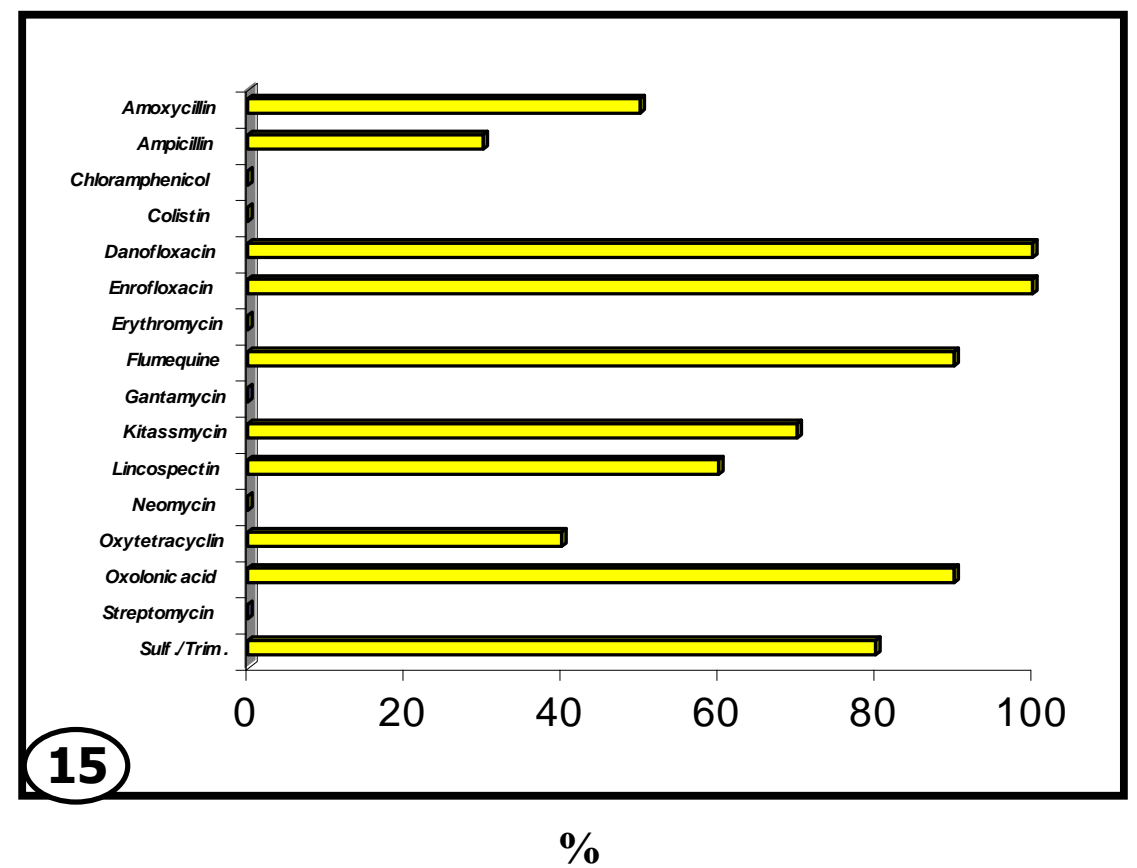

Fig. (15): Results of in-vitro sensitivity of S.marcescens isolates(n=28)to different antimicrobial agents.

Table (1): History of examined fish (O.niloticus) in the investigated fish farms in Kafr El-Sheikh Governorate. 


\begin{tabular}{|c|c|c|c|c|c|}
\hline $\begin{array}{c}\text { Code } \\
\text { No. }\end{array}$ & Locality & $\begin{array}{c}\text { Farm capacity } * / \\
\text { Fedan }\end{array}$ & $\begin{array}{c}\text { Age / } \\
\text { Months }\end{array}$ & $\begin{array}{l}\text { Average body } \\
\text { weight / Gram }\end{array}$ & $\begin{array}{c}\text { Mortality } \\
\% * *\end{array}$ \\
\hline 1 & Hamoul & 8 & 9 & 210 & 18.7 \\
\hline 2 & Hamoul & 5 & 6 & 155 & 12.5 \\
\hline 3 & Reyad & 7 & 6 & 160 & 19.8 \\
\hline 4 & Sedi-Salem & 8 & 5 & 110 & 20.9 \\
\hline 5 & Sedi-Salem & 6 & 4 & 5 & 21.4 \\
\hline
\end{tabular}

* Average 11000 fish / Fedan .

** Mortality : Recorded percentage during 10 days prior to the investigation.

No. $=$ Number. 
M. S. Gado, \& Iman A. Abd El-Aziz.

Table (3): Cultural and biochemical characteristics of bacteria isolated from $O$. niloticus fish .

\begin{tabular}{|c|c|c|}
\hline \multirow{2}{*}{\multicolumn{2}{|c|}{ Cultural characters }} & Isolates of red pigmented colonies on tryptic soy agar plates. \\
\hline & & $\mathrm{N}=\mathbf{2 8}$ \\
\hline \multirow{21}{*}{$\begin{array}{l}\text { API* } \\
20 \text { NE }\end{array}$} & ONPG & + \\
\hline & $\mathrm{ADH}$ & - \\
\hline & LDC & + \\
\hline & ODC & + \\
\hline & CIT & + \\
\hline & $\mathrm{H} 2 \mathrm{~S}$ & - \\
\hline & URE & - \\
\hline & TDA & - \\
\hline & IND & - \\
\hline & VP & + \\
\hline & GEL & + \\
\hline & GLU & + \\
\hline & MAN & + \\
\hline & INO & + \\
\hline & SOR & + \\
\hline & RHA & - \\
\hline & SAC & + \\
\hline & MEL & - \\
\hline & AMY & + \\
\hline & ARA & - \\
\hline & $\mathrm{OX}$ & - \\
\hline \multicolumn{2}{|c|}{ Catalase } & - \\
\hline \multicolumn{2}{|c|}{$\begin{array}{c}\text { The isolated } \\
\text { Pathogen }\end{array}$} & Serratia marcescens \\
\hline
\end{tabular}

* Code number : 08452. Lot- ch- B. 314962426 .

ONPG = Beta- galactocidase .

ADH $=$ Arginine hydrolase

LDC = Lysine decarboxylase .

ODC = Ornithine decarboxylase .

CIT = Citrate utilization.

H2S $=$ H2S Production.

URE = Urease .

TDA = Tryptophane desaminase.

SAC $=$ Sucrose [ fermentation/ oxidation] .

MEL = Meliliose [ fermentation/ oxidation] .

AMY = Amygtalin [ fermentation/ oxidation] .

ARA = Arabinose [ fermentation/ oxidation] .

OX = Cytochrome oxidase .
IND = Indole production.

VP $=$ Vogus Proskour .

GEL $=$ Gelatinase .

GLU = Glucose [ fermentation/ oxidation].

MAN = Manitol[ fermentation/ oxidation $]$.

INO = Inositol [ fermentation/ oxidation]

SOR $=$ Sorbitol [ fermentation/ oxidation] .

RHA = Rhamnose [ fermentation/ oxidation] .

Kafr El-Sheikh Vet. Med. J. Vol. 2 No. 2 (2004) 
Occurrence And Pathogenicity Of Serratia Marcescens ...

Table (4) : Virulence for fish and homoiothermic animals of S.marcescens.

\begin{tabular}{|c||c||c||}
\hline Groups No. & Animal species & Live cells LD $^{*}{ }_{\mathbf{5 0}}$ \\
\hline \hline 1 & O.niloticus $^{\mathrm{i}}$ & $1.0 \times 10^{5}$ \\
\hline 2 & M.cephalus $^{\mathrm{i}}$ & $5.0 \times 10^{3}$ \\
\hline 3 & Mice $^{\mathrm{i}}$ & $1.6 \times 10^{6}$ \\
\hline \multirow{2}{*}{4} & O.niloticus $^{\mathrm{c}}$ & None \\
\hline 5 & M.cephalus $^{\mathrm{c}}$ & None \\
\hline 6 & Mice $^{\mathrm{c}}$ & None \\
\hline
\end{tabular}

$\mathrm{I}=$ in fected .

$\mathrm{c}=$ control (uninfected) .

*= Mean lethal dose 50\% (LD50) was calculated as number of bacteria or Mg protein /g fish needed to kill $50 \%$ of inoculated animals .

\section{DISCUSSION}

Bacterial diseases remain of major economic and public health importance. We intend to deal with in this study to explore some new possibilities for diagnosis and control of one of the bacterial diseases that continue to cause problems for fish industries of the world. This will be done from point of view of the novel methods rather than from point of view of the disease.

The last 50 years have brought dramatic innovations in all fields of fish medicine.Significant scientific achievements and their organizational realization in the past have been outlined.

A large number of bacterial diseases occur in fish cultures (Noga, 1996). Among the bacterial diseases encountered in fish, S.marcescens infection has been documented as a cause of considerable economic loss to the fish cultures. To date, there are only four documented reports where Serratia species have been associated with fish disease(Nieto et al.,1990; Llewellyn, 1980; McIntosh and Austin, 1990; Baya et al., 1992). It is 
motile Gram-negative rod shaped and grow on tryptic soy agar media. The organism was closely resemble to many species of Enterobacteriaceae of clinical interest especially Yersinia ruckeri (Stevenson and Airdrie, 1984) and Aeromonas veronii (McIntosh and Austin, 1990) through it's morphological,colonial,biochemical characters and the septicemic lesions.

The bacterium could be distinguished from other similar pathogens (Baya et al.,1992).In the present investigation,outbreak of a disease associated with S.marcescens infection in 5 farms are described.To our knowledge there have been no reports of the infection or the disease in Oreochromic niloticus fish.S.marcescens could be isolated from internal skin, eyes and internal organs of the investigated commercial fish farms, which were suffering from anorexia, sluggishness, slow wasting, corneal opacity, haemorrhages and mortality up to $21.4 \%$. Similar finding in rainbow trout fish were made by Neito et al. (1990), in salmonids (Llewellyn, 1980; McIntosh and Austin, 1990). Moreover, we succeeded in isolation of S.marcescens from all investigated fish farms, which yielded 28 isolates. Because the organism can cause confusion with other similar bacteria species, the API 20 NE microtest system was a useful tool as a first diagnostic step and considered as a precise method for the identification and differentiation of S.marcescens from other bacteria that may cause similar clinicopathologic effects (Baya et al., 1992).According to the description of Grimont and Grimont (1984), the biochemical characteristics of the Serratia strain isolated in the present study from O.niloticus strongly sup-port its assignment to the species S.marcescens.

Moreover, most of the clinical signs observed in affected fish farms were similar to signs of infection caused by common bacterial pathogens of O.niloticus. The unusual eye opacity and haemorrhagic skin associated with high mortalities which developed in both affected fish farms and experimental infected fish help to distinguish the S.marcescens infection from others. 
On the other hand, the histopathological lesions in the examined fishes strongly confirned the S.marcescens infection and coincided with findings of Neito et al. (1990); McIntosh and Austin (1990), and Ullah and Arai (1983).

Furthermore, experimental infection of S.marcescens in susceptible fishes revealed interesting findings in all response variables measured in this trial when compared with the controls. The strains were highly pathogenic for O.niloticus. In addition, the S.marcescens isolated from O.niloticus was also virulent for Mugil cephalus, and was recovered from all the surviving fish 3 weeks post-inoculation, which indicates that the bacterium can establish a carrier state in this fish species. These findings congruent with those in rainbow fish reported by Baya et al. (1992).

Regarding the virulence assays for homoeothermic animals, S.marcescens strains were pathogenic for mice which coincided with the findings of Baya et al. (1992).

Over many years the scientific disciplines of genetics, husbandry, nutrition,microbiology and immunology were heavily engaged in the creation as well as in the proving of new ideas and concepts of thinking and realisation. Although the origin of S.marcescens in the apparently healthy O.niloticus is un known, it is probable that the high level of pollution of the area favoured the accumulation of the bacteruim in the fish. In fact, it has been demonstrated(Buras et al.,1985) that a high bacterial load in the water stresses the fish immune system and can result in invasion and proliferation in the fish tissues of environmental bacteria. Since the O.niloticus fish is a country-wide, we can rule out the risk of the dissemination of the Serratia to other geographic zones which is in accordance with Baya et al. (1992). In addition, the potential pathogenic capability for mammals exhibited by the O.niloticus isolate may be of public health concern since S.marcescens is a well-recognized opportunistic pathogen causing important human infections. 
Regarding the results of S.marcescens sensitivity in vitro; all tested isolates showed high sensitivity to danofloxacin and enrofloxacin. The lower incidence of antibiotic sensitivity among isolates of the organism to the other tested preparations might be due to increased resistance which in accordance with the findings of Baya et al. (1992). In addition, the drug resistance pattern exhibited by this isolates is typical of the majority of the S.marcescens strains studied (Grimont and Grimont, 1984).

The reason for the relatively late appearance of the scientific discipline of epizootiology in the scenario of disease outbreak is largely associated with the complexity of questions and the lack of appropriate tools to study and evaluate multiple inter-relationships.

This is the first report of S.marcescens being isolated and identified as a naturally occurring pathogen in O.niloticus fish. Because of its similarities with known O.niloticus fish pathogens, and its previously unreported occurrence in O.niloticus fish,S.marcescens effects and prevalence in fish industry are unknown.Clearly,additional biochemical tests are needed when identifying bacteria isolated from O.niloticus fish.

\section{ACKNOWLEDGEMENT}

The authors gratefully acknowledge the criticism of the work by Dr. A.A.El-Gohary, Prof. of Poult. Dis., Head of Poultry and Fish Dept., Fac. of Vet. Med. (Kafr El-Sheikh), Tanta Univ.

\section{REFERENCES}

- Austin, B., and D.A.Austin (1993): Bacterial fish pathogens. Diseases of farmed and wild fish, $2^{\text {nd }}$ ed. Ellis Horwood, Chichester.

- Baya, A. M.; A. E. Toranzo; B. Lupiani, and Y. Santos (1992): Serratia marcescens:a potential pathogen for fish. J. fish Diseases (15): 15-26.

- Bejerano, Y.; S. Sarig; M.T. Horne, and P. J.Roberts (1979):

Mass mortalities in silver carp.Hypophthalmichthys molitrix 
(Valenciennes), associated with bacterial infection following handling . Journal of fish Diseases (2): 49-56.

- Buras, N.; L. Duck, and S. Niv (1985) : Reactions of fish to microor-ganisms in wastewater. Applied and Environmental Microbiology (50): 989-995.

- Criuckshank, R.; J.R. Dugid; B.P. Mormion, and R.H.A. Swain (1975): Medical Microbiology. $12^{\text {th }}$ Ed. E.S. Livingstone Limited, Edi-nburgh, London, New York.

- Daily, O. P.; S. W. Joseph; J. C. Coolbaugh; R.I. Walker; B. R. Merrell;D.M.Rollins; R. J. Seidler; R. R. Colwell, and C. R. Lisser (1981): Association of Aeromonas sobria with human infection. Journal of Clinical Microbiology (13): 269-277.

- Fouz, B.; R. F. Conchas; J. Bolinches; J. L. Barja, and A. E. Tora-nzo (1990) : Relationship among pathogenic Vibrio anguillarum and Vibrio tubiashii with environmental vibrios . In: Pathology in Marine Science (ed. by T. C. Perkins, and R. Chen). Pp. 77-89 . Academic Press . New York.

- Gado, M. S., and Iman A. Abd El-Aziz (2003a): Studies on haemor-rhagic septicemia associated with Hafnia alvei in some freshwater fishes . Kafr El-Sheikh Vet. Med. J. Vol. 1 No. (1) Pp. 395-417.

- Gado, M. S., and Iman A. Abd El-Aziz (2003b): Prevalence of klebsiella pneumoniae associated with mortalities among Oreohromis niloticus as a new infection . Kafr El-Sheikh Vet. Med. J. Vol. 1 No. (2) Pp. 133-155.

- Gelev, I. ; E. Gelev ; A. G. Steigerwalt ; G. P. Carter, and D. J. Brenner (1990): Identification of the bacterium associated with haemorrhagic septicaemia in rainbow trout as Hafnia alvei. Research in Microbiology (141) : 573-576. 
- Grimont, P. A. D., and F.Grimont (1984): Genus VIII.Serratia Bizio 1923. In:Bergey's Manual of Systematic Bacteriology.Vol.1 (ed.by N. R. Krieg, and J. G. Holt).Pp.477-484.Williams, and Wilkins.Baltimore, Maryland.

- Lillie, R.D. (1984): Histopathological Techniques. $3^{\text {rd }}$ ed. The Blankiston Company, Philadelphia.

- Llewellyn, L. C. (1980): A bacterium with similarities to the redmouth bacterium and Serratia liquefaciens (Grimes and Hennerty) causing mortalities in hatchery reared salmonids in Australia. Journal of Fish Diseases (3): 29-39.

- McIntosh, D., and B. Austin (1990): Recovery of an extremely prote-olytic form of Serratia liquefaciens as a pathogen of Atlantic salmon, Salmo salar, in Scotland. Journal of Fish Biology (36): 765-772.

- National Committee for Clinical Laboratory Standards (1990): Performance standards for antimicrobial disk susceptibility tests. $4^{\text {th }}$ ed. Approved standard NCCLS document M2-A4, Villanova, Pa. 1990.

- Nieto, T. P.; L. R. López; Y. Santos; S. Núńez, and A. E. Toranzo (1990): Isolation of Serratia plymuthica as an opportunistic pathogen in rainbow trout, Salmo gairdneri Richardson. Jounal of Fish Diseases (13) : 175-177.

- Noga, E. J. (1996): Fish Disease: Diagnosis and Treatment. St. Louis, Missouri, 63146, Mosby-Year Book, Inc. U.S.A.

- Plumb,J.A., and P.R.Bowser(1983): Laboratory Manual of Microbial Fish Diseases. Auburn Univ., Auburn, Alabama. 
- Reed, L. J., and H. Müench (1938): A simple method of estimating fifty percent end points . American Journal of Hygiene (27): $493-497$.

- Sato, N.; N. Yamane, and T. Kawamura (1982) : Systemic Citroba-cter freundii infection among sunfish Mola mola in Matsushima aqua-rium. Bulletin of the Japanese Society of Scientific Fisheries (48): 1551-1557.

- Stevenson,R.M. W., and D. W. Airdrie (1984): Serological variation among Yersinia ruckeri strains. Journal of Fish Diseases (7): 247-254.

- Toranzo,A.E.;J.L.Barja;S. A. Potter; R. R. Colwell; F.M. Hetrick, and J.H.Crosa(1983): Molecular factors associated with the virulencc of marine vibrios isolated from striped bass in Chesapeake Bay. Infec-tion and Immunity (39): 1220-1227.

- Ullah,M.A., and T.Arai(1983): Pathological activities of the naturally occurring strains of Edwardsiella tarda. Fish Pathology (18): 65-70.

- West, P. A., and R. R. Colwell (1984): Identification of Vibrionaceae . An overiew. In: Vibrios in the Environment (ed. by R. R. Colwell). Pp. 285-263. John Wiley and Sons, New York.

$$
\begin{aligned}
& \text { حدوث وظهور إصابة مرضيه بميكروب السر اتيا مارسيسينز بمز ارع الأسمالك في } \\
& \text { محافظه كفر الثيخ } \\
& \text { د / محمد سعيد جادو ، " * / إيمان أحمد عبد العزيز }
\end{aligned}
$$

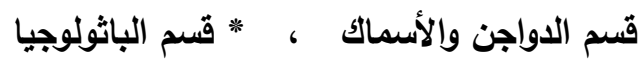

$$
\begin{aligned}
& \text { كلية الطب البيطري - جامعة طنطا - فرع كفر الثيخ } \\
& \text { أجري استقصاء عن حدوث وباء مرضي غير معتاد في خمسة مزارع بلطي نيلي أهليه تقع في }
\end{aligned}
$$

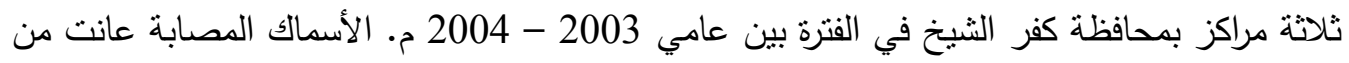


فقدان في الثهية، كسل، أنزفة جلدية ذات أحجام مختلفة، عنامة علي قرنية العين ونفوق عالي وصل

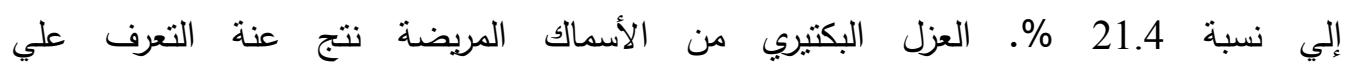
28 معزولة من ميكروب السراتيا مارسيسينز بواسطة الاختبارات البيوكيميائية.

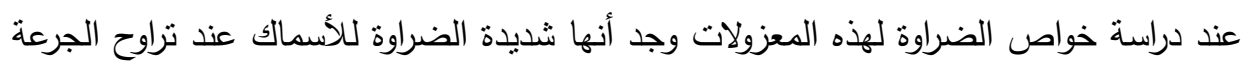
النصفية للوفاة بين 5 x 510 حتى 1 x 10 و وعلاوة علي ذلك تبين أن هذه المعزولات ضارية للفئران عند الجرعة النصفية للوفاة 1.6 x تم وصف التغيرات الهستوباثولوجية في الأسماك المريضة طبيعياً وكذا المعداه اصطناعبا. كما

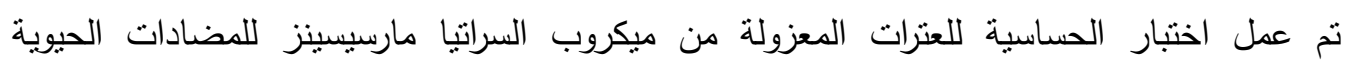

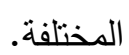

هذه الدراسة تعد الأولي من نوعها في نسجيل عدوى ميكروب السرانيا مارسيسينز لأسماك

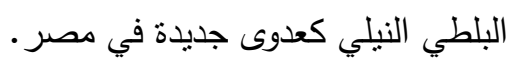

